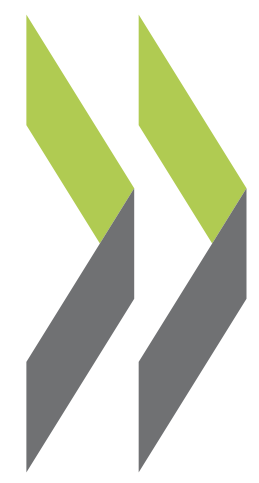

OECD Economics Department Working Papers No. 1148

\title{
Health, Work and Working Conditions: A Review of the European Economic Literature
}

\section{Thomas Barnay}

https://dx.doi.org/10.1787/5jz0zb71xhmr-en 


\section{Unclassified}

ECO/WKP(2014)44

Organisation de Coopération et de Développement Économiques

Organisation for Economic Co-operation and Development

21-Jul-2014

ECONOMICS DEPARTMENT

English - Or. English

HEALTH, WORK AND WORKING CONDITIONS: A REVIEW OF THE EUROPEAN ECONOMIC LITERATURE

ECONOMICS DEPARTMENT WORKING PAPERS No. 1148

By Thomas Barnay

OECD Working Papers should not be reported as representing the official views of the OECD or of its member countries. The opinions expressed and arguments employed are those of the author(s).

Authorised for publication by Robert Ford, Deputy Director, Country Studies Branch, Economics Department.

All Economics Department Working Papers are available through OECD's Internet website at www.oecd.org/eco/Workingpapers

JT03360596

Complete document available on OLIS in its original format

This document and any map included herein are without prejudice to the status of or sovereignty over any territory, to the delimitation of international frontiers and boundaries and to the name of any territory, city or area. 


\section{ECO/WKP(2014)44}

OECD Working Papers should not be reported as representing the official views of the OECD or of its member countries. The opinions expressed and arguments employed are those of the author(s).

Working Papers describe preliminary results or research in progress by the author(s) and are published to stimulate discussion on a broad range of issues on which the OECD works.

Comments on Working Papers are welcomed, and may be sent to the Economics Department, OECD, 2 rue André-Pascal, 75775 Paris Cedex 16, France, or by e-mail to eco.contact@oecd.org

This document and any map included herein are without prejudice to the status of or sovereignty over any territory, to the delimitation of international frontiers and boundaries and to the name of any territory, city or area.

\section{(c) OECD (2014)}

You can copy, download or print OECD content for your own use, and you can include excerpts from OECD publications, databases and multimedia products in your own documents, presentations, blogs, websites and teaching materials, provided that suitable acknowledgment of OECD as source and copyright owner is given. All requests for commercial use and translation rights should be submitted to rights@oecd.org 
ECO/WKP(2014)44

\section{ABSTRACT/RESUME}

\section{Health, Work and Working Conditions: A Review of the European Economic Literature}

Economists have traditionally been very cautious when studying the interaction between employment and health because of the two-way causal relationship between these two variables: health status influences the probability of being employed and, at the same time, working affects the health status. Because these two variables are determined simultaneously, researchers control endogeneity bias (e.g., reverse causality, omitted variables) when conducting empirical analysis. With these caveats in mind, the literature finds that a favourable work environment and high job security lead to better health conditions. Being employed with appropriate working conditions plays a protective role on physical health and psychiatric disorders. By contrast, non-employment and retirement are generally worse for mental health than employment, and overemployment has a negative effect on health. These findings stress the importance of employment and of adequate working conditions for the health of workers. In this context, it is a concern that a significant proportion of European workers (29\%) would like to work fewer hours because unwanted long hours are likely to signal a poor level of job satisfaction and inadequate working conditions, with detrimental effects on health. Thus, in Europe, labour-market policy has increasingly paid attention to job sustainability and job satisfaction. The literature clearly invites employers to take better account of the worker preferences when setting the number of hours worked. Overall, a specific "flexicurity" (combination of high employment protection, job satisfaction and active labour-market policies) is likely to have a positive effect on health.

This Working Paper relates to the 2014 OECD Economic Survey of the United States (www.oecd.org/eco/surveys/economic-survey-united-states.htm).

Classification JEL Codes: I18, I28, J28, J81

Keywords: work, health, working conditions, employment

$* * * * * * * * * * * * * * * * * * * * * * * * * * * * * * *$

\section{Santé, emploi et conditions de travail : Étude des publications économiques européennes}

Les économistes sont généralement très prudents lorsqu'il s'agit d'étudier les liens entre l'emploi et la santé, en raison du lien de causalité mutuel entre ces deux variables : l'état de santé joue sur la probabilité de travailler, tandis que le travail influe sur l'état de santé. Dans la mesure où les deux variables sont déterminées simultanément, les chercheurs prennent en compte les biais d'endogénéité (causalité inversée ou variables omises, par exemple) lorsqu'ils réalisent des analyses empiriques. Tout en gardant cette réserve à l'esprit, les études publiées montrent qu'un environnement de travail favorable et un niveau élevé de sécurité de l'emploi sont liés à un meilleur état de santé. Le fait d'avoir un emploi et de bonnes conditions de travail joue un rôle protecteur sur la santé physique et psychique. À l'opposé, le chômage comme la retraite sont généralement pires pour la santé psychique que l'emploi, et le suremploi a un effet néfaste sur la santé. Ces observations mettent en évidence l'importance de l'emploi et de bonnes conditions de travail pour la santé des actifs. Dans ce contexte, il est préoccupant de constater qu'une part significative des travailleurs en Europe (29\%) souhaiterait faire moins d'heures de travail, car le fait de travailler de longues heures sans l'avoir voulu traduit probablement un faible niveau de satisfaction professionnelle et des conditions de travail inadaptées, avec à la clé des conséquences néfastes sur la santé. C'est pourquoi en Europe, les politiques de l'emploi font de plus en plus attention à la pérennité de l'emploi et à la satisfaction professionnelle. Les études publiées invitent clairement les entreprises à mieux prendre en compte les souhaits des salariés quant au nombre d'heures travaillées. De manière générale, une «flexisécurité » spécifique (combinaison entre protection de l'emploi élevée, satisfaction professionnelle et mesures actives du marché du travail) devrait avoir des effets bénéfiques sur la santé.

Ce Document de travail se rapporte à l'Étude économique de l'OCDE de États-Unis 2014 (www.oecd.org/eco/etudes/etats-unis.htm).

Classification JEL : I18, I28, J28, J81

Mot clés : travail, santé, conditions de travail, emploi 
TABLE OF CONTENTS

HEALTH, WORK AND WORKING CONDITIONS: A REVIEW OF THE EUROPEAN ECONOMIC

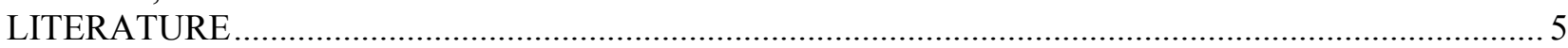

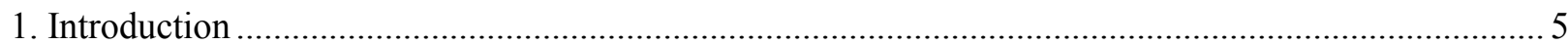

2. The measurement frame of health, and work and employment relations....................................... 6

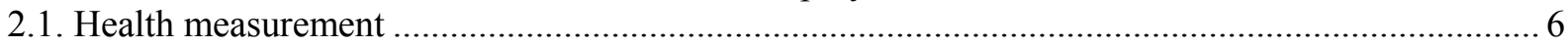

2.2 The Measurement of work and employment relations …….......................................................... 7

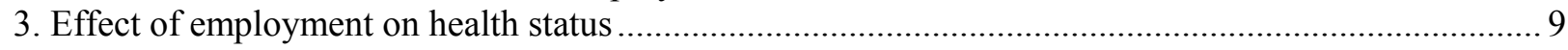

3.1. Effect of work and employment relations on physical health....................................................... 9

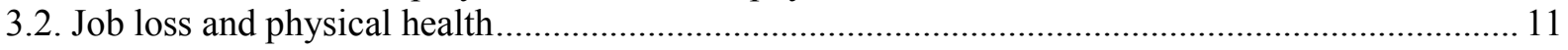

3.3. Impact of employment and working conditions on mental health ................................................ 12

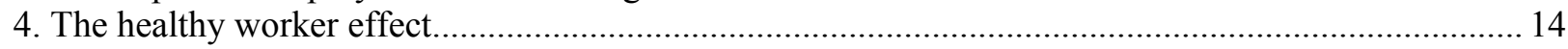

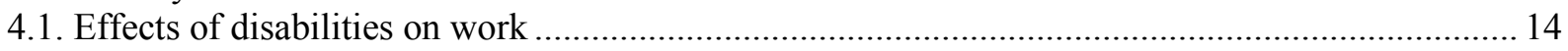

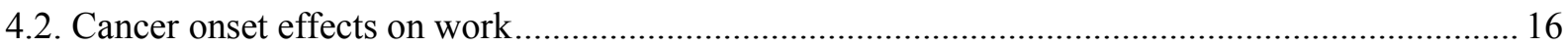

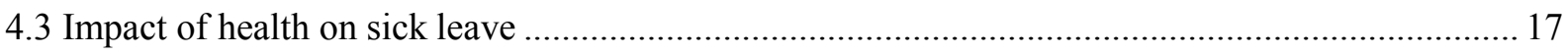

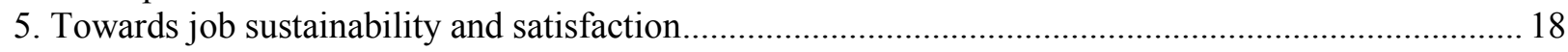

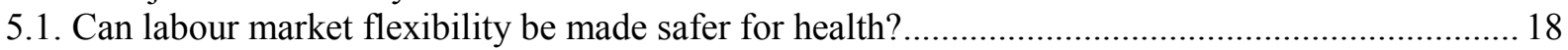

5.2. Avoiding health-scarring effects and easing labour-market reintegration.....................................20

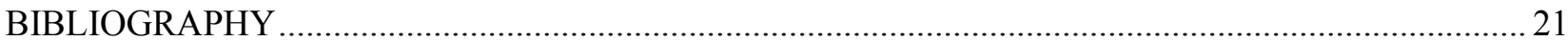


ECO/WKP(2014)44

\title{
HEALTH, WORK AND WORKING CONDITIONS: A REVIEW OF THE EUROPEAN ECONOMIC LITERATURE
}

\author{
Thomas Barnay ${ }^{1,2}$
}

\section{Introduction}

The interactions between health, work and working conditions have attracted considerable interest recently in Europe. A large part of European employees (EU27) - about 80\% - benefit from 'permanent contracts' which are stable and offer guarantees in terms of job security (EWCS 2010) ${ }^{3}$. Nevertheless, even these workers are being put under rising pressures by deep changes in labour-market trends. Job strain may have a large impact on health, and in return a deteriorated health status undermines employability. European workers experience a degradation of the quality of working life between 1995 and 2005 (Greenan et al., 2013). Almost one third of EU citizens report that work affects their health (EWCS 2010). When asked how work influences their health, $25 \%$ of Europeans declared work to be pathogenic. Conversely, only $7 \%$ reported work to be positive to their health. The average weekly working time has decreased from 40.5 hours in 1991 to 37.5 hours in 2010 due to the rising share of part-time jobs (38\% for women and $13 \%$ for men) and the declining share of people working very long hours (48 hours or more per week). Yet, more European workers say they would like to work fewer hours (31\%) than workers who say they would like to work more hours (16\%), suggesting a high level of dissatisfaction with working conditions (Eurofound, 2012). Moreover, European workers tend to be concerned about their exposure to risks of work-related injuries resulting from painful positions (reported by $46 \%$ of the European working population) as well as repetitive movements (63\%). The growing use of information and communication technologies and specifically computers (used frequently throughout the day by one third of the European workforce) contributes to this trend ${ }^{4}$.

The interaction between health and employment is the subject of numerous research studies and can be understood as a two-way causal relationship: employment has an impact on health and health has an impact on employment ("healthy worker effect") (Currie and Madrian, 1999; Lindeboom, 2006). Indeed, in a labour-market model, health status may be endogenous both in a structural sense (e.g., health and labour market outcomes are determined simultaneously) and in a statistical sense (e.g., unobserved heterogeneity). This study reviews, in European countries, empirical papers dealing with this two-way causal relationship.

The economic literature on the relationships between employment and health is sparse, compared to the vast number of studies published in other fields such as epidemiology, sociology and psychology.

1. $\mathrm{PhD}$, Assistant Professor in Economics. Erudite (Research team on the use of individual temporal data in economics); Tepp (CNRS 3435); Faculty of Economic Science and Management of the University ParisEst Créteil; Mail des mèches - Route de Choisy; 61, avenue du Général de Gaulle 94000, Créteil. France. barnay@u-pec.fr

2. I would like to thank Carissa Faulkner (OECD), Nathalie Greenan (CEE), Christine Le Clainche (CEE, ENS Cachan, Lameta), Patrick Lenain (OECD), Pierre-Jean Messe (CEE), Catherine Pollak (DREES) and Yann Videau (UPEC, Erudite) for their comments on a preliminary version and Eric Defebvre (UPEC, Erudite) for his help on Health at Work European policies.

3. The European Working Conditions Survey (EWCS) is an important source of information about working conditions, the quality of work and employment. The fifth ECWS concerns EU27, Norway, Croatia, the former Yugoslav Republic of Macedonia, Turkey, Albania, Montenegro and Kosovo.

4. In France, new work practices (e.g. quality norms, job rotation, flexibility of work schedules) are correlated with bad mental health and a detrimental work environment (Askénazy and Caroli, 2010). 
Economists have long been very cautious on this issue because causal mechanisms are difficult to identify and subjective variables are difficult to study ${ }^{5}$.

More research on these issues would be important because inadequate working conditions and poor job satisfaction negatively affect health, with costly consequences both for individuals and for society at large. At a broad level, the social costs of mental health have been estimated to be as high as $3 \%$ to $4 \%$ of GDP in the European Union (International Labour Organization). Sobocki et al. (2006) estimate that the total cost of psychological depression in Europe was EUR 118 billion in 2004 (e.g. about EUR 253 per capita). In some high-income countries, $40 \%$ of disability can be linked to mental disorders (WHO, 2010).

Furthermore, faced with unsustainable pension systems, European governments have raised retirement ages and/or increased the contribution period required to access full pension rights. However, despite the objective set at the Stockholm European Council to achieve an employment rate of $50 \%$ for those aged 55-64 years old by 2010, the European average was still only $47.4 \%$ in 2011 . Hard working conditions and health capital degradation contribute to lower productivity among older workers, increasing their take-up of sick leave and raising the risk of job loss (Blanchet and Debrand, 2005).

A better knowledge of the complex interactions between work and health is necessary to promote the prevention of occupational health risk, through the quest for new forms of organization that are less harmful for health. This should be a key priority of labour-market and health policies.

The paper is organized as follows. Section 2 deals with methodological issues around employment and health measurements. Section 3 describes the main results relative to the effect of employment on health. Section 4 presents the European literature relative to the healthy worker effect. In a final section, we discuss policy issues related to health at work.

\section{The measurement frame of health, and work and employment relations}

Various sources of bias may affect the assessment of health, work and employment relations, such as reporting biases related to the collection mode of information, skews in health and work measurements and justification biases.

\subsection{Health measurement}

\section{Reporting biases}

Biases are inherent in all surveys of self-reported subjective variables. Self-assessments, which are included in most health national surveys, are affected by social characteristics and individual health status, which can result in sociocultural and endogenous biases (Bound, 1991). Moreover, the comparability of results aggregated by categories such as social group, gender and age can be compromised by the existence of different norms and expectations, thus resulting in measurement errors (Akashi-Ronquest et al., 2011; Etilé and Milcent, 2006; Shmueli, 2003). Using the SHARE6 ${ }^{6}$ survey, Jürges (2007) explores Self-Assessed

5. As pointed out by Freeman (1978), "subjective variables like job satisfaction (...) contain useful information for predicting and understanding behavior" but "they also lead to complexities due to their dependency on psychological states" (about this second point, see section 2).

6. Share: Survey of Health, Ageing and Retirement in Europe. This longitudinal survey contains accurate data on health, employment and working conditions of a representative sample of individuals aged 50 and over in 11 European countries. This survey is equivalent of The Health and Retirement Study (HRS) in the USA. 
Health $(\mathrm{SAH})^{7}$ across European countries. They run an Oaxaca-Blinder decomposition of SAH to distinguish "true" health (captured by chronic diseases and objective health data such as grip strength, walking speed and Body Mass Index) and cross-cultural differences in reporting styles. They show that most of the differences between European citizens in better health (Denmark, Sweden) and those in worse health (Spain, Italy) is attributed to differences in reporting styles. To avoid these self-related biases, authors combine subjective measures of health status with objective measures, in particular indicators that pertain to the relation between health and employment. Based on SHARE data, Kalwij and Vermeulen (2008) confirm that the introduction of objective measures is required to control SAH endogeneity when assessing the impact of health on employment ${ }^{8}$. The most natural objective indicator is disability (see subsection 4.1), often assessed in surveys in terms of activity limitations ${ }^{9}$. Nevertheless, disability is only one aspect of health status and other health indicators must be used to take into account the multidimensional nature of health (Loprest et al., 1995).

\section{Justification bias}

Many articles in the literature deal with the potential existence of a "justification assumption" according to which self-reported health (or disability) would depend on people's labour-market situation. More precisely, people would tend to justify their labour force non-participation by over reporting a handicap (most frequently defined as a long-term health event that limits the type and quantity of work that people can perform). A series of studies tackles the issue of endogeneity between self-reported disability measures and labour force participation (Dwyer and Mitchell, 1999; Lindeboom and Kerkhofs, 2009; Benitez-Silva et al., 2004; Cai, 2009; Gannon, 2009; Akashi-Ronquest et al., 2011). Although some studies, such as that of Lindeboom and Kerkhofs (2009) and Gannon (2009) show, respectively on Dutch and Irish panel data, that the economic incentives related to labour-market status encourage people to misreport their disability status (even when controlling for unobserved heterogeneity as in Gannon, 2009), other studies conclude the opposite result ${ }^{10}$.

\subsection{The Measurement of work and employment relations}

Work is easier to measure than health. In microeconomic studies of labour supply, we traditionally distinguish two definitions of work: an intensive margin (working hours) and an extensive margin (employment status). In an intensive margin approach, a great deal of definitions has been studied in the epidemiological literature.

\section{The measurement of work relations}

Working conditions have been defined in seminal sociological and psychological papers. In particular, the Job Demand-Control (JD-C) Model, e.g. the imbalance model between perceived pressure (demand) and decision latitude (level of control), refers to concepts of job decision latitude, job demand and job

7. SAH is measured on a five point scale asking the question "How is your health in general; would you say it is...". SHARE contains two different 5-point scales for SAH, one ranging from 'excellent' to 'poor', the other from 'very good' to 'very poor'.

8. Moreover, SAH stay a good proxy of health status because it is highly correlated with objective measures such as mortality (Idler and Benyamini, 1997).

9. A very widespread question to measure activity limitation is "For the past six months at least, to what extent have you been limited because of a health problem in activities people usually do?" This question corresponds to the Global Activity Limitation Indicator (GALI) which is standardized, at European level, through The Minimum European Health Module.

10. This is notably the case of Cai (2009) on Australian data. 
strains (Karasek, 1979; Karasek and Theorell, 1991). In its basic form, the JD-C Model postulates that the primary sources of job stress lie within both job's basic characteristics: psychological job demands (high pressure of time, high working pace, difficult and mentally-demanding work) and job decision latitude (worker's ability to control his own activities and skill usage) or job control. Strong job demand combined with low job control leads to a high-strain jobs. This situation called "job strain" is associated with a higher propensity to cardiovascular disease, as well as in mental health problems (Kivimaki et al., 2006; Bonde, 2008). Job strain potentially concerns a high number of EU workers as about $60 \%$ report having a highly-demanding job and more than a third reports low autonomy in their job (EWCS 2010). The situation becomes even more detrimental in the case of social isolation (i.e. lack of social support at work from the hierarchy and/or colleagues). An "iso-strain" situation is detected in the case of job strain combined with a lack of social support and leads to deteriorating physical health, notably cardiovascular diseases (Lindblom, 2006).

Siegrist's model (1996) introduces Effort-Reward-Imbalance (ERI). Rewards are provided to employees by three potential channels: money (i.e., adequate salary), esteem (e.g. respect and support) and security/career opportunities (e.g. promotion prospects, job and employment status securities). Siegrist shows that high effort-low reward leads to increased cardiovascular risk and psychiatric disorders. Even if the scope is broader, the ERI model appears close to the prediction of the theory of compensating wages differentials. Workers with the same productivity should receive different wages if they perform tasks of different levels of difficulty in a pure and perfect competition model. This is the Hedonic Price Wage theory, proposed by Rosen in 1974, which reflects the size of the heterogeneity of wages.

\section{The measurement of employment relations}

More recently, other concepts have emerged concerning psychosocial factors at work. From an economic standpoint, four dimensions were especially stressed: duration of working time (van der Hulst, 2003), extended working time (van der Hulst, op.cit.), job insecurity (Sverke et al., 2006) and job satisfaction.

A majority of European workers (55\%) are satisfied with working the same number of hours as they currently do. However, a significant proportion would like to work fewer $(31 \%)$ or more $(14 \%)$ hours (EWCS 2010). There are important differences concerning the responses when controlled for age, gender, employment status and current working hours. The main factors increasing the willingness to work more hours are: being a man, being young and already working long hours. People willing to decrease their working hours are mainly: working atypical hours, working in a high-intensity job and those in the lowestincome bands. Working part time may have a positive impact on one's life as it is associated with achieving a better balance between working life and private life, as well as having a better health status. Those who work part time are less likely to say they have good career prospects, but those working long hours face work-life conflicts. The same can be said for people working atypical hours (night work and 'on call' workers representing around $20 \%$ of the European working population) (EWCS 2010).

The fear felt by a worker of losing his job relates to the job-insecurity concept. In Europe, overall, job security prevails as about $90 \%$ of public, health and education sector workers are expecting to keep their job for the next 6 months, but this figure is much lower for industry and construction workers (resp. 79\% and $78 \%$ ) (EWCS 2010).

In sum, the various aspects of working conditions could be embodied by the concept of job satisfaction which refers to employment relations. Job satisfaction is often used as an overall summary of feelings about how workers consider their job. This concept is particularly important as the feelings of work-related satisfaction or dissatisfaction contribute to overall quality of life (Drobnič et al., 2010). Timming (2010) showed that being supported by the hierarchy, being safe in the job, having a good 
balance between life and work, satisfaction with pay (Siegrist, op.cit.) and having opportunities to "learn and grow" were significant factors of high job satisfaction in most European countries. Another study from Sousa-Poza et al. (2000), on the basis of International Social Survey Program (ISSP), added the importance of having an interesting job. A specific part of the literature also focused on the importance of a good match between workers' skills and duties (a mismatch potentially leading to dissatisfaction and reduced well-being; Green, 2011).

Bassanini and Caroli (2014), in economic review, show that the effect of work on health changes according to individual preferences. Unwanted long hours and an obligation to stay in employment affect an individual's health status. This is very similar to a work-leisure trade-off in a neoclassical model of labour supply (Allen, 1981) in the case of intensive margin. Within this framework, the negative impact of work on health could correspond to the differential between the contractual number of hours and the desired number of hours.

\section{Effect of employment on health status}

Employment affects health via a variety of potential channels, such as risk behaviours, healthcare access, material life or early-life conditions and cumulative effects. Risk behaviours (tobacco, alcohol or drug consumption, sedentariness, etc.) are determining factors in the early occurrence of chronic disease. These behaviours are more widespread in disadvantaged environments (Stronks et al., 1997, in the Netherlands). Marmot (2000) shows that a third of the variance in mortality rates due to coronary disease can be attributed to tobacco consumption, high blood pressure or sedentariness. Access to healthcare could equally play a role in the causal relationship between employment and health status. In France, the Statutory Health Insurance scheme covers the quasi totality of the population; only $6 \%$ remain without complementary health insurance (CHI) coverage. Among individuals without $\mathrm{CHI}$ coverage, $46 \%$ selfreport financial reasons. Furthermore, coverage levels among the CHI beneficiaries are extremely heterogeneous. The more generous company-provided CHI reinforces the social health inequalities between the employed and the non-employed populations and also within the working population: $76 \%$ of executives benefit from employer-provided CHI against only 58\% of unskilled workers and $53 \%$ of trade sector employees (Perronnin et al., 2011). Favourable socioeconomic conditions result in access to better healthcare quality through access to better information and a higher degree of preventative behaviour. Furthermore, better professional integration improves the income level and thereby increases the opportunities to invest in one's health through sport, healthy diet, better housing conditions and even better working conditions. By improving one's material living conditions, the improved socioeconomic status leads to a better health status. The literature has shown that an improvement in living conditions is conducive to a better health status, whether it is defined in terms of income (Ecob and Davey Smith, 1999 in England, Wales and Scotland; Fiscella and Franks, 2000 in 21 countries and territories), employment status (Mesrine, 2000 in France), working conditions, education level (van Rossum et al., 2000 in the Netherlands), socio-demographic factors (Grundy and Holt, 2000 in Great Britain) or living environment and neighbourhood (Bosma et al., 2001 in the Netherlands). In following subsections, we focus on the health effect of working conditions (3.1) - in a large sense - and unemployment/retirement (3.2). In subsection 3.3., we describe the effect of working conditions on the specific topic of mental health.

\subsection{Effect of work and employment relations on physical health}

The interactions between work and employment relations and workers' health conditions have received considerable attention in epidemiology and health economics fields. Psychosocial factors, such as the feeling of hierarchical dominance or the loss of autonomy or deprivation, increase the probability of exposure to stress and psychological distress. An individual's socio-professional situation will thus favour (or not) the emergence of psychosocial problems that will lead to deterioration in health status. 
Llena-Nozal (2009) and Datta Gupta and Kristensens (2008) show, with longitudinal data and crosscountry comparisons, that a favourable work environment and high job security lead to better health conditions, after controlling for unobserved heterogeneity.

The physical health of workers who have part-time jobs is worse than those who are full-time (Gash et al., 2007 in West Germany and Spain; Waenerlund et al., 2011 in Sweden; Robone et al., 2011 in UK; Carrieri et al., 2012 in Italy). For instance, on 12 waves of the BHPS ${ }^{11}$, Robone et al. (op.cit.) estimate current SAH and a reduced version of the $\mathrm{GHQ}^{12}$ by a dynamic panel ordered probit specification with correlated random effects, controlling for prior health status. Having a part-time job (as compared to fulltime job) has an asymmetric impact on health for both men and women according to preferences for the number of work hours. Their results suggest that the impact of part-time work is positive only among upper social classes. Reversely, individuals with unsecure contractual conditions experience bad health if their jobs are associated with low levels of employability.

In order to identify the specific effect of the employment contract on health, it is necessary to control for observed and unobserved heterogeneities because the choice of job allocation is unlikely a random experience (due to heterogeneity of individual preferences, risk aversion attitudes, working conditions and health status among population). It is known that contract workers can be characterized by poorer physical and psychological working conditions (Burchell, 1994). Taking into account unobserved heterogeneity and selection effects (e.g. self-selection of workers with a lower health status into temporary employment) in panel data, studies find significantly reduced (indeed no) effects of the contract on the physical and mental health (Cottini and Lucifora, 2013; Ehlert and Schaffner, 2011).

Cottini and Lucifora (op.cit.) use EWCS data (waves 1995, 2000, 2005) and study 15 EU countries. They investigate the role of working conditions on mental health. They implement IV strategy relying on variation across countries in terms of workplace health and safety regulation in order to identify the causal effect of bad working conditions on mental health. They find that job quality (in particular job demands) affect mental health. Based on the EU-SILC data (2004-2008) ${ }^{13}$, Ehlert and Schaffner (op.cit.) use a fixedeffects ordered logit model to measure the impact of a work contract on SAH. They propose two ways in order to control for selection effects. In a first specification, they restrict the sample to young labour market entrants (below 30) who join the labour market after education. In a second specification, in order to control for negative health effects following temporary employment, they restrict the analysis to those with temporary contracts who changed their job due to the end of a contract. They find no health differences between labour market entrants according to contract (temporary or permanent employment). However, they observe a negative effect of additional temporary employment on SAH (in reference to a full employment contract).

The average working time in the EU27 was 37.5 hours a week (EWCS 2010). About 25\% of European workers were part time workers while $13 \%$ were concerned by working long hours. Is this population prone to a greater risk of health capital deterioration? Robone et al. (op.cit.) show that a preference for less working hours causes bad SAH among both the men and women population (the reverse is also true, but only for men who want to work longer). Combining a part-time job and preferences for less working hours is associated to bad SAH for women. However, long working hours increase

11. British Household Panel Survey.

12. General Household Questionnaire.

13. The European Union Statistics on Income and Living Conditions (EU-SILC) allows to collect timely and comparable cross-sectional and longitudinal multidimensional microdata on income, poverty, social exclusion and living conditions. EU-SILC is organised under a framework regulation and is thus compulsory for all EU Member States. The EU-SILC data cover all EU countries except Malta. 
psychiatric disorders (Cottini et al., op.cit.) ${ }^{14}$. Bell et al. (2012) analyse the effect that hours constraints (difference between actual working hours and desired working hours) have on different measures of workers' health (SAH and health satisfaction) in Germany $\left(\right.$ G-SOEP $\left.^{15}\right)$ and the UK (BHPS) by using fixedeffects ordered logit models. For both countries, overemployment causes negative effects on both health measures.

\subsection{Job loss and physical health}

Job loss is associated with bad individual well-being (Clark et al., 2008). A priori, the persistence of massive unemployment and recurrent forms of non-employment has a deteriorating effect on health status $^{16}$. Numerous European studies focus on the relationship between unemployment and poor health (Kalwij and Vermeulen, 2008 in Europe; Böckerman and Ilmakunnas, 2009 in Finland; Eliason and Storrie, 2009 in Sweden; Haan et Myck, 2009 in Germany) and on the effects of retirement on health (In Europe : Coe and Zamarro, 2011 and for international comparison, see Rohwedder and Willis, 2010). Once again, this relationship is subject to endogeneity; lower health in the unemployed than in the employed could be explained by reverse causality.

To check this assumption, using the European Community Household Panel (ECHP) ${ }^{17}$ for Finland over the period of 1996-2001, Böckerman and Ilmakunnas (2009) implement Chamberlain's random effect estimation in an ordered probit model to measure the impact of unemployment on health. Using G-SOEP data, Schmitz (2011) estimates, for Germany, a fixed effect model. He finds no significant health effect (measuring by health satisfaction, hospital visits and mental health score). Their results demonstrate that unemployment does not appear to have a significant negative effect on $\mathrm{SAH}^{18}$.

To tackle the problem of endogeneity, studies focus on job loss due to plant closure. Using administrative data panel in Denmark in the period 1980-2006, Browning and Heinesen (2012) estimate the causal effects of job displacement due to plant closure on mortality and hospitalization outcomes among the male workers population in the private sector by using propensity score weighting. They find that job loss increases the overall mortality risk and especially circulatory disease, suicide mortality, death and hospitalization due to traffic accidents, alcohol-related disease and psychiatric disorders. These results converge with Kuhn et al. (2009) using Austrian data, which find a positive effect of job loss due to plant closure on public health expenditures generated by additional psychotropic drugs consumption and hospitalization cost due to mental problems and stroke among male population (matching procedure with propensity score). From NPSLC ${ }^{19}$ (1997-2002) and the 2003 EU-SILC, Osthus (2012) estimates a dynamic probit model (with unobserved heterogeneity) on Norwegian data. The author plays down the results of previous studies because they only measure a transitory negative effect on mental health and show no effect on physical health.

14. See table 2 on p. 968 (before IV implementation). After endogeneity control, Table 5 don't show detailed results of job demands. Overall findings therefore lead to validate negative role of job demand on mental health.

15. The German Socio-Economic Panel (G-SOEP) is a longitudinal survey of approximately 11000 private households from 1984 to 2012 (in the Federal Republic of Germany), and from 1990 to 2012 (in eastern German Länder).

16. To review the effect of job loss on overweight and drinking see Partha et al., 2011.

17. ECHP (European Community Household Panel) is built from Annual interviews of a representative panel of households and individuals in each European Union (EU) country.

18. These results corroborate Browning et al., 2006, for Denmark.

19. Norwegian Panel Survey of Living Conditions. 
The nature of the causal relationship between retirement and health is not obvious and can be bidirectional due to retirement endogeneity. Retirement may first free individuals from a job strain situation and may improve, in particular, short-term mental health. This positive dynamic will be sustainable as long as individuals have a capacity to invest in their health (via an income effect) $\left(\right.$ Grossman, $1972^{20}$ ). Conversely, a retirement shock can also cause a loss of a social role (Kim and Moen, 2002, USA), a decline in human capital stock and therefore a deterioration of health will be enhanced by a negative shock on living standards of the retiree. Bad health status results in early retirement from the labour market (Bound et al., 1999; Dwyer and Mitchell, 1999; Kerkhofs et al., 1999; in France: Barnay 2010; Barnay and Briard, 2011). Thus, retirement can be desired by unhealthy, old European workers. Using SHARE data (2004 wave), Blanchet and Debrand (2005) conduct an endogenous selection model by controlling for monetary factors and in particular, the structure of pension entitlements. They show that bad health and job dissatisfaction are significant determinants in the desire to retire as early as possible. From the same European data, Coe and Zamarro (2011) measure the effect of retirement on health (by using country-specific early and full retirement ages as instruments). They conclude that retirement decreases the probability of reporting bad health $(35 \%)$, after controlling for endogeneity (reverse causality). Nevertheless, this effect is not observed with both measures of depression ${ }^{21}$. In the UK, Bound and Waidmann (2007) examine both SAH and objective health measures effects of retirement using one wave of the ELSA ${ }^{22}$. They find a positive but transitory health effect in retirement only for men. In France, using the Barometre Santé dataset (1993 and 2005) and both econometric strategies (difference-indifferences and IV method), Garrouste and Blake (2012) study the impact of retirement on different Duke $\operatorname{scores}^{23}$. They show that retirement has a positive impact on physical health (difficulty walking up a flight of stairs) for low-educated individuals.

\subsection{Impact of employment and working conditions on mental health}

Methodological difficulties in measuring health seem even more pronounced in relation to mental health. Devaux et al. (2008) attempted to assess the reporting bias linked to mental health. They conclude that a latent health status strongly contributes to mental health: two people may declare different mental health levels according to their physical health. Indeed, a person with poor physical health is more likely to report poor mental health. The role of latent health status in the declaration of mental disorders seems to be confirmed, especially by Leach et al. (2008), on the basis of Australia data, which show a strong correlation between physical and mental health, and particularly in the female population. This gender effect is confirmed by Barnay and Defebvre (2014) in a French study. From an IV approach using the Health and Professional Itinerary Survey (Santé et Itinéraire Professionnel, SIP), they show that poor mental health in the male population decreases the probability of staying in employment after including physical health as control variables. In the female population, physical health is predominant on their professional trajectory and there is no specific effect of mental health on employment.

In addition, omitted variables generate unobserved individual heterogeneity, which is also a potentially endogenous factor. Risk preferences (Zhang et al., 2009), job involvement and satisfaction (Nelson et al., 2008), family background (Banerjee et al., 2013) and risk behaviours (smoking, alcohol and overweight) are all related to both mental health and employment.

20. Galama et al. (2012) extended the structural model of Grossman with endogenous retirement age.

21. They use two depressions measures: Euro-D depression scale and a simple indicator variable relative to sadness or depression during the last month.

22. ELSA: English Longitudinal Study of Aging.

23. The Duke Health Profile (DUKE) is a 17-item generic self-report instrument containing six health measures (physical, mental, social, general, perceived health, and self-esteem), and four dysfunction measures (anxiety, depression, pain, and disability). 
We examine three categories of determinants: employment, working conditions and long-term effects of initial conditions.

Overall, being employed plays a protective role on psychiatric disorders. In the Netherlands Plaisier et al. (2008) use cross sectional data to measure various social roles (employee, partner and parent) with the prevalence of anxiety and depressive disorders ${ }^{24}$ (without correcting for endogeneity). Both having a job and working full time were associated with a lower prevalence of anxiety disorders and depression among men, but not among women. The effect of employment is confirmed in a robust econometric study of the UK based on a fixed-effect dynamic panel data model for mental health ${ }^{25}$ (LlenaNozal et al., 2004). Gender differences are corroborated. Employment status is a determining factor for males but not for females. The effect of retirement on health status seems significant when considering mental health indicator. On the basis of SHARE data, and using Instrumental Variables (IV) strategies, Mazzonna and Peracchi (2012) find a negative impact of retirement on mental health ${ }^{26}$ after properly controlling for several identifications issues (retirement endogeneity, cohorts and retirement effects heterogeneity in particular). This mental retirement effect can be attributed to a decrease in human capital investment and an "unengaged lifestyle hypothesis" (Rohwedder and Willis, 2010). Non-employed men have substantially worse mental health. From the 1994 Catalonian Health Survey, Artazcoz et al. (2004), without endogeneity control, the authors show that non-employment is associated with problems of mental health for men and to a lesser extent for women in Spain. If being in employment appears as a tool of good mental health's promotion, especially among men, the working conditions can be potentially pathogenic and provoke mental health problems.

Using longitudinal surveys for the UK (BHPS, 1991-2005), Switzerland (SHP ${ }^{27}$, 1999-2005), Australia and Canada, Llena-Nozal (2009) estimate, by performing a fixed-effect panel model, the impact of changes of hours worked on an indicator of mental distress. Non employment is generally worse for mental health than employment.

In France, among men and women, constrained part-time work is associated with a higher depression. From the 2003 Decennial Health Survey, Santin et al. (2009) show that having a fixed-term contract is correlated with depression, but only for women. Workers on temporary contracts may suffer more psychological costs and stress due to exposure to job insecurity (Ferrie, 2001; Ferrie et al., 2005; Chenga Yawen et al., 2005; Green, 2011; Caroli and Godard, 2013). Thus, Bildt et al. (2002) show that exposure to difficult working conditions may have an adverse effect on mental health, with differences according to gender. Men are more affected by changes in tasks and a lack of pride at work. Among women, other drivers explain this effect, such as no training, low motivation and weak social support at work. Men suffer from the omnipresence of work in their lives and the repetitiveness and lack of cooperation in the labour force. Women, in addition to the repetitive nature of tasks and lack of cooperation, identify starting work before age 18 and involuntary interruptions during work as criteria impacting their health. Using Karasek (1979) and Johnson et al. (1989) models, Laaksonen et al. (2006) show that stress at work, job demand, weak job decision, lack of justice and support induce bad health.

Significant life events also play a role in determining the current state of mental health. Unemployment and non-employment, during the beginning of working life can induce depressive

24. Psychiatric disorders are measured using a computerized version of the Composite International Diagnostic Interview.

25. Mental health is assesses through the Malaise Inventory designed by the Institute of Psychiatry from the Cornell Medical Index.

26. The cognitive ability is defined from tests of orientation in time, memory, verbal fluency and numeracy.

27. Swiss Household Panel. 
symptoms later. Workers who have higher risk of long-term unemployment suffer from feelings of job insecurity and face a higher risk of mental health than others (OECD, 2013). It has been shown that events such as illness or the death of a close relative or partner, marital separations, and serious quarrels also tend to impact mental health (Lindeboom et al., 2002 in the Netherlands, Dalgard et al., 2006 in five European countries). Past or present financial difficulties are also often associated with the onset of common mental disorders, such as depression and anxiety (Weich et al., 1998). Finally, a degradation in physical condition induced impairment of mental health, especially for women (Leach et al., 2008). Bad health or the presence of disability in childhood has negative consequences on mental health at older ages, as well as chronic diseases, regardless of the age of onset (Llena -Nozal et al., 2004).

\section{The healthy worker effect}

The healthy worker effect refers to the selection of workers in good health and reflects past personal experience having undermined health and professional paths. For instance, several studies attach importance to the cumulative effects of events experienced throughout an individual's life cycle having reinforced the selection effect. An individual's socioeconomic situation during childhood, or even in utero (according to the latency hypothesis or latency model, Barker, 1995; Wadsworth, 1999), and labour market trajectory described as the pathway model (Case et al., 2005) are important determinants of health status in adulthood. Lindeboom et al. (2006) show that the childhood environment influences the probability of experiencing occupational accidents and disabilities. A large body of literature equally acknowledges the role played by the social determinants of health (Marmot and Wilkinson, 1999; Berkman and Kawachi, 2000).

Moreover, we can observe a self-selection of workers with a lower health status into, for instance, temporary employment or specific jobs. Tackling this selection problem can lead to invalidate the negative effect of temporary contracts on health status (Cottini and Lucifora, 2013; Ehlert and Schaffner, 2011).

Selection effects must be taken into account to measure the net effect of work on health. Several empirical strategies are used to correct the different sources of bias described above. This is very difficult in cross-sectional approaches; researchers use instrumental variables (IV) and bivariate probit methods, but they face problems of weak instruments ${ }^{28}$. The best strategy relies on panel data which enables control for unobserved time-invariant individual and temporal heterogeneities

\subsection{Effects of disabilities on work $^{29}$}

In this main field, we select two topics: the effectiveness of legislative and fiscal measures relative to handicaps and the impact of handicaps on professional paths.

A first category of studies deals with the effects of disability insurance benefits programmes (in terms of eligibility criteria and generosity), notably provisions seeking to maintain disabled persons in employment (Staubli, 2011; Marie and Vall Castello, 2012). Vall-Castello (2012) evaluated the effects of a policy promoting employment among disabled women in Spain. The author studies the impact of reducing social security contributions for employers who hired disabled women. The study uses a difference-indifferences method with a recursive bivariate probit model to evaluate the existence of changes in trends for the employment of females in relation to that of males due to the policy, conditional on any pre-existing trends. It shows a significant effect from the reductions of the Social Security employer contributions and

28. Indeed with IV method, the "cure can be worse than the disease" (Bound, Jaeger and Baker, 1993).

29. The first part of this sub-section was partially co-written with E. Duguet, C. Le Clainche, M. Narcy and Y. Videau in a work in progress called "The Impact of Disabilities on Occupations: A Comparison Between Public and Private Sectors". 
estimates an average elasticity of employment with respect to these reductions of 0.08 for women with long-term disabilities. Other studies have also used the difference-in-differences method to examine the influence of the disability insurance programs on individuals' professional careers. Along the same lines, Staubli (2011) studies, in the case of Austria, the effect of linking the eligibility to disability insurance to return to work and disability enrolment. They identify a statistically significant positive effect for this type of measure on labour market participation (in the private sector) for disabled men aged 55 and over (an increase of 1.6 to 3.4 points). The method is based on a study of differences over time and according to a gender-age mix. Marie and Vall Castello (2012) look into the impact of establishing a more generous disability insurance programme on the rate of labour market participation for claimants suffering from partial disability (who can combine disability benefits and job income) for individuals aged 55 and over (the only ones eligible for such benefit increases). Using Spanish data, the authors find that a $36 \%$ increase in the amount of disability pensions reduces the probability of being employed by $8 \%$.

A second category of studies has to do with the impact of disability on labour-market outcomes, including professional careers. Jones (2011) estimates the influence of different characteristics of disability (type, origin, duration, severity) on the probability of being employed and on labour-market earnings, using an ad hoc module of the 2002 UK Labour Force Survey. The study only includes people reporting disabilities and estimates are made separately for men and women. Selection effects due to only considering employees experiencing disabilities are taken into account. The results reveal a positive influence of disability at birth on employment, but only for men, as well as a positive influence of disability resulting from a traffic accident for both men and women. On the other hand, mental illness negatively affects employment both for men and women. Disability's form has far less influence on earnings than it has on employment.

Furthermore, two other articles are based on a rather similar methodology, using matching methods with temporal lag between the occurrence of the health shock leading to disability and the evaluation of outcomes in terms of vocational integration. Lechner and Vazquez-Alvarez (2011) estimate the effect of becoming disabled (officially recognized) on labour market outcomes: employment, unemployment, exiting the labour market, net annual earnings and per capita household disposable income, and average weekly hours worked. They use German panel data from 1984 to 2002 that they cut into sequences of four successive years and implement propensity score matching. The individuals belonging to the control group, the so-called "untreated", are individuals not officially recognised as disabled over the four-year sequence while the "treated" are individuals officially recognized as disabled between the first and second years of the sequence, with the authors insisting on the objectivity of the disability measure. The matching was carried out on observable characteristics over the first year and matching variables correspond to the characteristics susceptible of influencing the occurrence of a disability. They then compare the different outcomes (unemployment, employment...) between the treated and the untreated in $t_{2}, t_{3}$ and $t_{4}$ and obtain the following results: disability does not lead to a reduction in earnings nor in hours worked, at least during the three years following the occurrence of a disability, when the disabled person remains employed; becoming disabled reduces the probability of being employed by $9 \%$ and approximately $13 \%$ for those with a high degree of disability three years after its onset. Nonetheless, this reduction in the probability of being employed is not accompanied by an increase in the probability of being unemployed, which could be interpreted in terms of a "voluntary" employment exit.

More than disability stricto sensu, Garcia-Gomez (2011) studied the impact of a health shock on labour-market outcomes in nine European countries on the basis of the ECHP. The author notably uses the propensity score method with two consecutive health state measures enabling an estimate of the occurrence of a health shock (the perceived health deterioration and illness prevalence) and targets test and control groups depending on the sequence during which the health shock occurred. He thus studies the health shock over three years, considering in $t_{1}$ a person in good perceived health and in employment in $t_{1}$ and $t_{2}$. The treated group is that which is in poor health in $t_{2}$ and $t_{3}$, which implies that the shock lasts at least until 
$t_{3}$ while individuals in this group were in good health in $t_{1}$. The control group is in good perceived health in $t_{1}, t_{2}$ and $t_{3}$. The results, obtained by applying matching methods, suggest that health shocks have a significant causal effect on the probability of employment: persons suffering from a health shock are much more susceptible of leaving their job and transiting through disability.

In France, using cross-sectional French data, Tessier and Wolff (2005) analyse the population aged 25 to 55 using a discreet time simultaneous equation model. The authors clearly establish the impact of health on labour market participation from an individual's entry into employment. On the other hand, professional activity does not appear to have an impact on health. Barnay and Legendre (2012) try to establish from a model of simultaneous equations and a latent variable model (Simultaneous bi Ordered probit) a full explanation of the relationship between health and occupational status. The results corroborate three assumptions: a healthy worker effect, a negative causal effect of occupational integration on disease prevalence, and positive causal effect of occupational integration on self-perceived health and activity limitation.

Moreover, still using data from France, Duguet and Le Clainche (2012 b,c) developed a series of studies on the relation between chronic illnesses and employment. They show a negative causal effect of a health shock on the probability of being employed, in particular for low-skilled workers. Exploiting the 2006 Health and Professional Itinerary Survey (Santé et Itinéraire Professionnel, SIP) wave and by applying a differences-in-difference with exact matching method, they show that non-professional health events penalise low-skilled people more heavily. The latter is already weakened on the labour market and transiting more frequently from employment to unemployment, while individuals possessing a secondary or higher level of education remain employed more often.

Previous studies consider that the disability is based on a self-reported indicator or from an administrative recognition. We can also assume that sick leave constitutes an objective inability to work. It is essentially the Scandinavian authors who studied the impact of sick leave on professional paths. Hansen (2000) shows a negative effect of taking sick leave on wage trajectory in Sweden but only among women, each additional sick day reducing their wage rate by $0.2 \%$. Hesselius's study (2007) in Sweden stresses that an increase of sick leave and their frequency enhances the risk of unemployment. More recently, Markussen (2012) in Norway establishes that an increase of one percentage point in the rate of sick leave decreases the probability of being employed two years later. For those remaining in employment, the author also observes a negative impact of sick leave on wages.

\subsection{Cancer onset effects on work}

In a meta-analysis based on 26 papers using US and European data, de Boer et al. (2009) estimate the relative risk of unemployment of cancer survivors to 1.37 in reference to a healthy population, all other things being equal. In a review of 64 international articles Mehnert (2011) shows that the return to work of cancer survivors, on average, is equivalent to $40 \%$ six months after the diagnosis, $62 \%$ after twelve months, $73 \%$ after eighteen months and $89 \%$ after twenty-four months. Conversely, the onset of cancer leads to a transitory or permanent exit from the labour market. At a given age and gender in Finland, the relative risk of early retirement is 2.2 for survivors of cancer of the nervous system, 2 for leukemia, 1.9 for tongue, 1.2 for breast and 1.1 for prostate (Taskila-Abrandt et al., 2005).

The negative impact of cancer on the career path passes mostly through functional limitations (Bradley et al., 2002, USA) that may be specific, such arm pain for breast cancer (Quinlan et al., 2009 in Canada , Blinder et al., 2012, USA) as well as depressive episodes (Damkjaer et al., 2011, Denmark), disorders of concentration and memory (Oberst K. et al., 2010, USA) and more generally, more pronounced psychosocial risks (Cooper et al., 2012, UK). These dynamics are more or less supported according to the nature of the initial endowments of human capital, the difficulty of working conditions 
before the illness but also the type of cancer (site, severity disease) and finally, the nature of the treatment (Mujahid et al., 2011; Lindbohm et al, 2011; Johnsson et al., 2011; Blinder et al., 2012). Past professional biography (unemployment or training episodes) can lead to stigmatizing effects on the careers of individuals (Heckman and Borjas, 1980; Tominey and Gregg, 2005) and, for some social groups, predicts the occurrence of professional cancers.

The work environment also influences the job quality after the onset of the disease. In a literature review, Feuerstein et al. (2010) stress the importance of improvements in the workplace in terms of schedule flexibility, social support from colleagues, social climate and job stress. Using French data Duguet and Clainche (2012a) show that the probability of RTW for French employees two years after the cancer's diagnosis increases when appropriate working conditions were implemented.

\subsection{Impact of health on sick leave}

Socioeconomic characteristics play a large role on sick leave determinants. Thus, women generally take longer and more frequent sick leaves than do men (in France - Chaupain-Guillot and Guillot, 2007; Ben Halima and Regaert, 2013; In Europe Union - Frick and Malo, 1008; Livanos et al., 2010). They are thus more sensitive to economic incentives (compensation system effect) and are more influenced by unemployment (Henrekson and Persson, 2004; Ose, 2005). Moreover, the length of sick leaves increases with age, without them occurring more frequently. This surprising result can be partially explained by the existence of a healthy worker effect; employed seniors are healthier than those who are not employed.

Indeed, health status is equally a determining factor. A degradation of the health capital could lead to sick leave by making the individual unable to work. In addition, the preservation of health capital can benefit from periods of preventive sick leaves in order to avoid more damaging consequences on the individual's occupational status (Grossman, op.cit.). Case and Deaton (2005) explain that manual workers self report to be in the poorest health status. In France, Chaupain-Guillot and Guillot (op. cit.) demonstrated that a person suffering from a chronic disease or disability has a higher probability of taking sick leave. Furthermore, Ben Halima and Regaert (op.cit.) highlight that an individual with an acute chronic disease $(\mathrm{ACD})^{31}$ takes longer sick leave.

In the Shapiro-Stiglitz efficiency wage model (1984), the individuals whose utility positively depends upon wages and negatively upon effort would be less inclined to be voluntarily absent (shirking model) when the probability of finding a new job is lower. Thus, the critical wage (the minimum wage satisfying the non-shirking condition) is an increasing function of the expected utility associated with unemployment. Ben Halima and Regaert (op.cit.) demonstrate a negative relationship between wages and the length of sick leaves (in which case leisure is considered to be a normal good) by controlling those individuals with $A C D$ while Chaupain-Guillot and Guillot (op. cit.) indicate that the impact of wages on the probability of absence in men is negative, corroborating the shirking model.

Concerning the type of work contract, a permanent contract increases the probability of returning to work (Ben Halima and Regaert, op.cit.). Women with a fixed-term contract have a lower probability of being absent (Chaupain-Guillot and Guillot, op. cit.). In economic theory, absenteeism results from a workleisure trade-off in a neoclassical model of labour supply (Allen, 1981; Brown and Sessions, 1996). Within this framework, sick leaves could correspond to the differential between the contractual number of hours and the desired number of hours. For instance, women working part time (ensuring a better balance

30. This sub-section was partially co-written with S. Juin and R. Legal in a work in progress called "Disparities in taking sick leave between sectors of activity in France: a longitudinal analysis of administrative data" (see in references: Barnay et al., 2014).

31. In France, the costs of 30 Acute chronic diseases (ACD) are fully paid by the social security. 
between family and professional lives) have a lower probability of absence (Chaupain-Guillot and Guillot, op. cit.).

Based on Shapiro and Stiglitz (1984), it is commonly argued that labour market uncertainty has a negative impact on absenteeism (in other words, absenteeism is countercyclical) but empirical evidence has to be more nuanced. We can assume that the unemployment rate constitutes a worker disciplining device and employees may fear losing their job if they report sickness. Nevertheless, the duration of sick leave is determining. Thus, Ose (2005) found that short-term absences (shorter than 3 days) do not depend on the unemployment rate while long-term absences do. Using micro-data from the EU LFS ${ }^{32}$ for 28 countries, Livanos and Zangelidis (2013) showed that a higher proportion of dependents persons (inactive and unemployed individuals) is associated to lower sickness absence, probably due to the pressure active people may experience. Afsa and Givord (2009), using French data, show that a high percentage of absenteeism among unskilled workers is, in fact, due to irregular working hours. ChaupainGuillot and Guillot (op. cit.) reveal that a person unsatisfied with their work has a higher probability of absenteeism. Moreover, the positive relationship between the company's size and the probability of absence due to illness (Ben Halima and Regaert, op. cit.; Ose, 2005) seems to confirm the importance of working conditions. Nevertheless, this positive relationship could also reveal differences in checking policies or individual effort within the company.

\section{Towards job sustainability and satisfaction}

Keeping in mind what we know about the interactions between employment, working conditions and health, policymakers face the following two objectives:

1. For insiders, improving job sustainability and satisfaction by reducing the impact of unwanted professional shocks on health status and the exposure to arduous working conditions (subsection 5.1).

2. Increasing the (re)integration of outsiders (healthy or unhealthy persons) to avoid permanent exclusion from the labour market and negative effects of unwanted non-employment on health status (subsection 5.2).

\subsection{Can labour market flexibility be made safer for health?}

EU treaties and policy directives recognize the importance of preserving the health and safety of workers and maintaining their well-being: "Work shall be adapted to individuals and not individuals to work" (European Commission, 1989). The EU strategy 2007-2012 on health and safety at work restates the prime objective of "an ongoing, sustainable and uniform reduction in accidents at work and occupational illnesses" (European Commission, 2007). The EU Council adopted the requirement of "improvement in the working environment to protect workers' health and safety", putting an explicit responsibility on the employer to adapt the work to the individual, especially as regards to the design of work places, the choice of work equipment and the choice of working and production methods' (European Commission, 1989). The question of choice is central.

European policies converge towards a single objective: job sustainability. This concept, referring to the ability of people in employment to maintain this situation throughout all of their career is one of the key guideline for public policies. Older European workers with disabilities are more likely to be employed if they benefit from higher rewards (Pollak, 2012). In its broader meaning, job sustainability refers to key factors affecting participation in paid employment, such as health, training, lifelong learning, availability of

32. European Union's Labour Force Survey. 
a care infrastructure, marketable skills and motivation. For this matter, several national policies have been implemented all over Europe. In the Netherlands, the Ministry of Social Affairs and Employment introduced the Action Plan Healthy Business, aiming at promoting primary, secondary and tertiary prevention of the physical and psychosocial workloads. In Italy, the Ministry of Labour launched a campaign tackling work-related diseases, with a special focus on musculoskeletal disorders and respiratory diseases. The Davy report in France granted security to workers when changing jobs.

The empirical economic literature clearly invites employers to take better account of the worker preferences when setting the working time and the number of hours worked. This chosen flexibility could decrease the negative effects of work on health. Indeed, part-time working can be a worker's choice or it can be involuntary. While $25 \%$ of EU27 workers are employed part time, this proportion varies greatly from $49 \%$ in the Netherlands to about $25 \%$ in Austria, Belgium, Denmark, Germany, Ireland, Norway, Sweden and the UK. In the Netherlands, about one quarter of men work part time and one third of women. Working-time preferences differ among European countries. EWCS 2010 suggests that the proportion of workers satisfied with their working time varies across countries: $71 \%$ in Bulgaria, $64 \%$ in Romania, between $60 \%$ and $62 \%$ in Luxembourg, Belgium and Poland, but only $38 \%$ in Sweden. $31 \%$ of European workers would prefer to work less per week than they currently are (49\% in Sweden, $44 \%$ in Greece and $41 \%$ in Denmark vs. $17 \%$ in Bulgaria and $26 \%$ in Belgium and Italy). Finally, $14 \%$ of European workers would prefer to work more per week than they currently are. The motivations for reduced working time can be explained by poor health status care needs, harsh working conditions or concern for a better balance between professional and personal life. Motivations for increased working time may come from an income effect and/or a high job satisfaction. It seems that the use of free time is different according to social class preferences (Bassanini and Caroli, op.cit.). Several hypotheses can be proposed. Accordance with the model of Grossman, saving time given to the upper classes, who decide to work less, allowing them directly produce good health (care consumption) and also indirectly through utility-related better reconciliation of private and professional lives. The effect of part-time work dominates the loss of health induced by a reduction in income. In contrast, among the disadvantaged classes part-time work can appear more undergone. The negative effect of the loss of income on health effects dominates the other. A better understanding of these behaviours could be a support tool for health at work.

Moreover, with the growth of specific strains on workers, such as organizational and psychosocial risk factors, the impact of work on mental health is becoming stronger. In 2008, a European Pact for Mental Health and Well-being was established at the EU level, and focuses on the improvement of work organization and the hierarchical practices in order to promote mental well-being, to assess and prevent the impact of specific behaviours such as stress, violence, harassment and drug use, and finally to help people suffering from mental disorders to return to the labour market.

Mental health becomes a major issue owing to the development of new technologies, management methods, activity controls (quality standards, processes rationalization, etc.) as well as contacts with the public. Some European countries already implemented specific policies to deal with these new threats of work. In the Netherlands, the Safe Public Service program aims at reducing violence towards public employees. Belgium launched a campaign in order to reduce stress at work and violence, including that shown on TV spots. Some policies are targeting strains resulting from poverty and insecurity, as a noticeable proportion of workers report experiencing great difficulties in making ends meet when in the context of a high unemployment rate. Thus, the European platform against poverty and social exclusion goal is to support work and help people out of poverty: by 2020, at least 20 million people should be pulled out of social exclusion.

Finally, within this specific topic on mental health, Cottini and Lucifora (op.cit.) show that the efficiency of health care systems (in terms of medical density, GP visits, beds available for psychiatric care, health care expenditure per capita) and labour market (e.g. employment protection legislation, 
unemployment benefits) seem to allow a better trade-off between job quality and mental health. They show that these characteristics of the healthcare market and the labour market appear to protect such countries as France and the Netherlands but do the opposite for Sweden.

\subsection{Avoiding health-scarring effects and easing labour-market reintegration}

It is necessary to invest in ongoing training from the beginning of a professional career to offset adverse health shocks. In Europe, more than a half of the working population reports a good match between their skills and what their job requires. However, younger workers and those using information and communication technologies report the need for training more often. Many proposals have also been made to encourage lifelong learning and to enable workers to develop their employability. An 'Agenda for new skills and jobs' is proposing reforms in order to help people to gain the right skills for future jobs in Europe. This programme was followed in several countries, such as Austria and Italy, by specific national reforms. Another programme called 'Youth on the move' targets young students and trainees. It proposes to gain experience on the job market by increasing mobility and promoting education in Europe. A programme also targeting youth was implemented in the UK.

Austria and Hungary worked on policies specifically aiming at people at risk of losing their job, or people not being able to find a job due to their health status. Finland made arrangements for the rehabilitation of workers after a sickness absence. France has adopted policy initiatives going in this direction such as the 2005 Law for equal rights and opportunities, the participation and citizenship for the disabled that completes 1987 law on behalf of employment for people with disabilities ${ }^{33}$. Econometric studies show that reducing social security contributions for employers who hired disabled people allows an increasing employment rate in Spain and demonstrates efficacy of specific measures.

The literature review shows a negative impact of retirement on mental health. To avoid these adverse effects, retirement should be a gradual and chosen path. It should, therefore, develop opportunities to promote work after retirement and the reversibility of retirement. This phenomenon is growing in Europe. From 2005 to 2011, most European countries experienced an increase of employment rates among 65 to 69-year-olds, particularly in Finland, the UK, Lithuania, Germany and Austria. Flexible work arrangements have been identified as crucial in facilitating post-retirement work (Reday-Mulvey, 2005). A natural way to target work after retirement is to facilitate self-employment for 65 to 69 -year-olds.

To conclude, it seems desirable to combine flexibility and employment security by taking into account individual preferences in Europe. As Origo et al. (2009) showed after properly controlling for endogeneity, "a temporary but secure job (hence, the lack of only job stability) seems preferable to the combination of a permanent but insecure job (that is, the lack of only job security)". A search field is still largely under invested. It is a question of one hand if health is affected by instability of employment or income instability and, on the other hand, to better identify the trade-off between loss of income and increase in job satisfaction. For instance, if instability is primarily related to income, then a strategy of flexicurity with generous unemployment or disease benefits or over a short period would allow individuals to smooth their consumption of health care even in case of loss of job and be a good strategy against the negative effects of employment shocks on health.

33. Law 87-517 of 10 July 1987 made it compulsory for all employers (public and private) having over 20 paid workers, assessed as full time equivalent workers, to employ disabled workers (OETH) representing at least $6 \%$ of the total employees, under penalty of financial sanctions (with the exception of the public sector). 
ECO/WKP(2014)44

\section{BIBLIOGRAPHY}

Afsa, C. et P. Givord (2009), « Le rôle des conditions de travail dans les absences pour maladie : le cas des horaires irréguliers ». Économie et Prévision, 187, pp. 83-103.

Akashi-Ronquest, N., P. Carrillo, B. Dembling, S. Stern, (2011), "Measuring the Biases in Self-reported Disability Status: Evidence from Aggregate Data", Applied Economics Letters, 18(11), pp. 10531060 .

Allen, S.G. (1981), “An Empirical Model of Work Attendance”, The Review of Economics and Statistics, 63(1), pp. 77-87.

Artazcoz, L., J. Benach, C. Borrell, I. Cortes (2004), "Unemployment and Mental Health: Understanding the Interactions among Gender, Family Roles, and Social Class", American Journal of Public Health, 94(1), pp. 82-88.

Askenazy, P. and E. Caroli (2010), "Innovative Work Practices, Information Technologies and Working Conditions: Evidence for France", Industrial Relations, 49 (4), pp.544-565.

Banerjee, S., P. Chatterji, K. Lahiri (2013), "Effects of Psychiatric Disorders on Labor Market Outcomes: A Latent Variable Approach Using Multiple Clinical Indicators", CESifo Working Paper, No. 4260.

Barker, D. J. P. (1995), “Foetal Origins of Coronary Heart Disease”, Britain Medicine Journal, 311, pp. 171-174.

Barnay, T. et E. Defebvre (2014), «L'impact de la santé mentale sur le maintien dans l'emploi quatre ans plus tard », Document de Travail Erudite, n ${ }^{\circ}$ 01-2014.

Barnay, T., S. Juin, R. Legal (2014), "Disparities in Taking Sick Leave between Sectors of Activity in France: a Longitudinal Analysis of Administrative Data", Tepp Working papers, No. 14-01, 27.

Barnay T. and F. Legendre (2012), "Simultaneous Causality between Health Status and Employment Status within the Population Aged 30-59 in France", Tepp Working papers, No. 12-13.

Barnay T. and K. Briard (2011), "Health and Early Retirement: Evidence from French Data for Individuals", Economics Bulletin, 31(1), pp. 324-341.

Barnay T, (2010), "In Which Ways Do Unhealthy People Older than 50 Exit the Labour Market in France?”, European Journal of Health Economics, 11(2), pp. 127-140.

Bassanini, A. and E. Caroli (2014), "Is Work Bad for Health? The Role of Constraint vs Choice," IZA Discussion Papers 7891, Institute for the Study of Labor (IZA).

Bell, D., S. Otterbach and A. Sousa-Poza (2012), "Work Hours Constraints and Health", Annales d'Economie et Statistiques, n¹05-106, pp. 35-54.

Ben Halima, M. A. and C. Regaert (2013). "Duration of Sick Leave, Income and Health Insurance:

Evidence from French Linked Employer-Employee Data". Economics Bulletin 33(1), pp. 46-55. 
ECO/WKP(2014)44

Benitez-Silva, H., M. Buchinsky, H. Man Chan, S. Cheidvasser, J. Rust (2004), "How Large is the Bias in Self-Reported Disability?", Journal of Applied Econometrics, 19, pp. 649-670.

Berkman, L. and I. Kawachi (2000), Social Epidemiology, New York: Oxford University Press.

Bildt, C. and H. Michelsen (2002), "Gender Differences in the Effects from Working Conditions on Mental Health: a 4-year Follow-Up", International Archives of Occupational and Environmental Health, 75(4), pp. 252-258.

Blake, H. and C. Garrouste (2012), "Collateral Effects of a Pension Reform in France", Health Econometrics and Data Group Working Paper No. 12/16, York.

Blanchet, D. et T. Debrand (2005), « Aspiration à la retraite, santé et satisfaction au travail : une comparaison européenne », Insee Première, 1052.

Blanchet, D. et T. Debrand (2007). « Souhaiter prendre sa retraite le plus tôt possible : santé, satisfaction au travail et facteurs monétaires », Économie et Statistique, n 403-404, pp. 39-62.

Blinder, V.S., S. Patil, A. Thind, A. Diamant, C. A. Hudis, E. Basch, R. C. Maly (2012), "Return to Work in Low-income Latina and non-Latina White Breast Cancer Survivors: a 3-year Longitudinal Study", Cancer, 118 (6), pp. 1664-1674.

Bound, J., and T. Waidmann (2007),"Estimating the Health Effects of Retirements", Michigan Retirement Research Center, Working Papers No. 168, University of Michigan.

Bound, J., M. Schoenbaum, T-R. Stinebrickner et T. Waidmann (1999), "The Dynamic Effects of Health on the Labor Force Transitions of Older Workers", Labour Economics, 6(2), pp. 179-202.

Bound, J. (1991), "Self-Reported Versus Objective Measures of Health in Retirement Models", Journal of Human Resources, 26, pp. 106-38.

Böckerman, P. and P. Ilmakunnas (2009), "Unemployment and Self-assessed Health: Evidence from Panel Data", Health Economics, 18(2), pp. 161-179.

Bonde, J. P. (2008), "Psychosocial Factors at Work and Risk of Depression: A Systematic Review of the Epidemiological Evidence", Occupational and Environment Medicine, Vol. 65, No. 7, 2008, pp. $438-445$.

Bosma, H., H. Dike van de Mheen, G. J. J. M. Borsboom and J. P. Mackenbach (2001), "Neighborhood Socioeconomic Status and All-cause Mortality". American Journal of Epidemiology, 153(4), pp. 363-371.

Bradley, C. J., H. L. Bednarek, D. Neumark (2002), "Breast Cancer Survival, Work, and Earnings", Journal of Health Economics, 21(5), pp. 757-779.

Browning, M., and E. Heinesen (2012), "Effect of Job Loss Due to Plant Closure on Mortality and Hospitalization", Journal of Health Economics, 31(4), pp. 599-616.

Browning, M., A. Moller Dano, E. Heinesen (2006). "Job Displacement and Stress-related Health Outcomes", Health Economics, 15, pp. 1061-1075. 
Brown, S, and J.G. Sessions (1996), "The Economics of Absence: Theory and Evidence". Journal of Economic Surveys, 10, pp. 23-53.

Burchell, B. (1994), "The Effects of Labour Market Position, Job Insecurity and Unemployment on Psychological Health", in Gallie, D, Marsh, C and Vogler, C (eds) Social Change and the Experience of Unemployment, Oxford : Oxford University Press, pp. 188-212.

Cai, L., (2009), “Is Self-Reported Disability Status Endogeneous to Labour Force Status?”, Applied Economic Letters, 16(5), pp. 459-464.

Carrieri, V., C. Di Novi, R. Jacobs and S. Robone (2012), "Well-being and Psychological Consequences of Temporary Contracts: the Case of Younger Italian Employees", CHE Research Paper, No. 79, University of York.

Caroli, E. and M. Godard (2013), "Does Job Insecurity Deteriorate Health? A Causal Approach for Europe", PSE Working Paper, No. 2013-01.

Case, A. and A. Deaton (2005), "Broken Down by Work and Sex: How Our Health Declines, in D. Wise (ed.), Analyses in the Economics of Aging, University of Chicago Press.

Case, A., A. Fertig, C. Paxson (2005), "The Lasting Impact of Childhood Health and Circumstance," Journal of Health Economics, 24, pp. 365-389.

Coe, N. and G. Zamarro (2011), "Retirement Effects on Health in Europe", Journal of Health Economics, 30(1), pp. 77-86.

Cohidon, C., G. Santin, E. Imbernon, M. Goldberg (2010), "Working Conditions and Depressive Symptoms in the 2003 Decennial Health Survey: the Role of the Occupational Category", Social psychiatry and psychiatric epidemiology, 45(12), pp. 1135-1147.

Cooper A. F., M. Hankins, L. Rixon, E. Eaton, E. Grunfeld (2012), "Distinct Work-related, Clinical and Psychological Factors Predict Return to Work Following Treatment in Four Different Cancer Types", Psycho-oncology, Doi: 10.1002/pon.3049.

Cottini, E. and C. Lucifora (2013), "Mental Health and Working Conditions in European Countries", Industrial and Labor Relations Review, 66(4), pp. 958-988.

Chaupain-Guillot, S. et O. Guillot (2007), «Les absences au travail : une analyse à partir des données françaises du Panel européen des ménages ». Economie et Statistique, 408-409, pp. 45-80.

Currie J. and B. C. Madrian (1999), "Health, Health Insurance and the Labor Market", in Handbook of Labor Economics, Ashenfelter O., D. Card, (eds), Amsterdam, North Holland, pp. 3309-3416.

Dalgard O., C. Dowrick, V. Lehtinen, J. Vazquez-Barquero, P. Casey, G. Wilkinson, J. Ayuso-Mateos, H. Page, G. Dunn (2006), "Negative Life Events, Social Support and Gender Difference in Depression: A Multinational Community Survey with Data from the ODIN Study", Social Psychiatry Psychiatric Epidemiology, pp. 444-451.

Damkjaer, L. H., Deltour, I. Suppli, N. Palm, J. Kroman, H. T. Johansen, C. Dalton, S. Oksbjerg (2011), "Breast Cancer and Early Retirement: Associations with Disease Characteristics, Treatment, Comorbidity, Social Position and Participation in a Six-day Rehabilitation Course in a Registerbased Study in Denmark", Acta oncologica, 50(2), pp. 274-281. 
Datta Gupta and N. Kristensen (2008), "Work Environment Satisfaction and Employee Health: Panel Evidence from Denmark, France and Spain, 1994-2001", The European Journal of Health Economics, vol. 9(1), pp. 51-61.

Debrand, T. and P. Lengagne (2007), "Pénibilité au travail et santé des seniors en Europe", Economie et Statistique, n403-404, pp. 19-38.

Drydakis, N., (2012) "Health Impaired Employees Job Satisfaction New Evidence from Athens, Greece", Applied Economics Letters, 19(8), pp. 789-793.

De Boer, A. G, T. Taskila, A. Ojajarvi, F. J. van Dijk, J. H. Verbeek (2009), “Cancer Survivors and Unemployment : a Meta-analysis and Meta-regression", Journal of the American Medical Association; 301(7), pp. 753-762.

Debrand, T. and P. Lengagne (2007), «Pénibilité au travail et santé des seniors en Europe », Economie et Statistique, 403-404, pp. 19-38.

Devaux, M., F. Jusot, C. Sermet, S. Tubeuf (2008) : « Hétérogénéité sociale de déclaration de l'état de santé et mesure des inégalités de santé », Revue Française des Affaires Sociales, 1, pp. 29-47.

Duguet E., Le Clainche (2012a), « Une évaluation de l'impact de l'aménagement des conditions de travail sur la reprise du travail après un cancer », Document de travail CEE, 159.

Duguet E., Le Clainche (2012b), "The Impact of Health Events on Individual Labor Market Histories: The Message from Difference-in-Differences with Exact Matching", LAMETA DR n²012-08; Working paper Serie.

Duguet E., Le Clainche (2012c), "Chronic Illnesses and Injuries: An Evaluation of Their Impact on Occupations and Revenues", Document de travail CEE, $\mathrm{n}^{\circ} 155$.

Drobnič, S., B. Beham and P. Präg (2010), 'Good Job, Good Life? Working Conditions and Quality of Life in Europe', Social Indicators Research, Vol. 99, No. 2, 2010, pp. 205-225.

Dwyer, D., O. Mitchell (1999), "Health Problems as Determinants of Retirement: Are Self-Rated Measures Endogenous?", Journal of Health Economics, 18(2), pp. 173-193.

Ecob, R. and G. Davey Smith (1999), "Income and Health: What is the Nature of the Relationship?", Social Science \& Medicine, 48(5), pp. 693-705.

Ehlert, C. \& S. Schaffner (2011), "Health Effects of Temporary Jobs in Europe", Ruhr Economic Papers 0295, Rheinisch-Westfälisches Institut für Wirtschaftsforschung, Ruhr-Universität Bochum, Universität Dortmund, Universität Duisburg-Essen.

Eliason, M., D. Storrie (2009), "Does Job Loss Shorten Life?," Journal of Human Resources, 44(2), pp. 277-302.

Étilé, F. and C. Milcent (2006): "Income-related Reporting Heterogeneity in Self-assessed Health: Evidence from France", Health Economics, 15(9), pp. 965-981.

Eurofound (2012), "Fifth European Working Conditions Survey", Publications Office of the European Union, Luxembourg. 
Eurofound (2012), "Income from Work after Retirement in the EU", Publications Office of the European Union, Luxembourg.

Ferrie, J. (2001), "Is Job Insecurity Harmful to Health?”, Journal of the Royal Society of Medicine, 94, pp. 71-76.

Ferrie, J., M. Shipley, K. Newman, S. Stansfeld and M. Marmot (2005), "Self-reported Job Insecurity and Health in the Whitehall II Study: Potential Explanations of the Relationship", Social Science \& Medicine, 60, pp. 1593-1602.

Feuerstein, M., B. L.Todd, M. C. Moskowitz, G. L. Bruns, M. R. Stoler, T. Nassif, X. Yu (2010), "Work in Cancer Survivors: a Model for Practice and Research", Journal of Cancer Survivorship, Research and Practice, 4, pp. 415-437.

Fiscella, K. and P. Franks (2000), "Individual Income, Income Inequality, Health, and Mortality: What Are the Relationships?" Health Services Research, 35(1-2), pp. 307-318.

Freeman, R. B. (1978), "Job Satisfaction as an Economic Variable", The American Economic Review, 68(2), pp. 135-41.

Frick, B. and M. A. Malo (2008), "Labor Market Institutions and Individual Absenteeism in the European Union: the Relative Importance of Sickness Benefit Systems and Employment Protection Legislation". Industrial Relations 47(4), pp. 505-529.

Galama, T., A. Kapteyn, A. Fonseca, P-C Michaud (2013), “A Health Production Model with Endogenous Retirement”, Health Economics, 22(8), pp. 883-902.

Gannon, B., (2009), “The Influence of Economic Incentives on Reported Disability Status", Health Economics, 18(7), pp. 743-759.

Gash, V., A. Mertens and L. Romeu Gordo (2007), "Are Fixed-term Jobs Bad for Your Health? A Comparison of West Germany and Spain”, European Societies, 9, pp. 429-458.

Garcia-Gomez, P., (2011) "Institutions, Health Shocks and Labour Outcomes across Europe," Journal of Health Economics, 30(1), pp. 200-213.

Green, F. (2011), "What is Skill? An Inter-disciplinary Synthesis", Centre for Learning and Life Changes in Knowledge Economies and Societies, London.

Greenan N., E. Kalugina, E. Walkowiak (2013), "Has the Quality of Working Life Improved in the EU-15 between 1995 and 2005?", Industrial and Corporate Change; doi: 10.1093/icc/dtt012.

Gregg P. and E. Tominey (2004), "The Wage Scar from Youth Unemployment," The Centre for Market and Public Organisation, No. 04/097, Department of Economics, University of Bristol, UK.

Grossman M. (1972). "On the Concept of Health Capital and the Demand for Health". The Journal of Political Economy 80(2), pp. 223-255.

Grundy E. and G. Holt (2000), "Adult Life Experiences and Health in Early Old Age in Great Britain". Social Science \& Medicine, 51(7), pp.1061-1074. 
Hansen J. (2000), “The Effect of Work Absence on Wages and Wage Gaps in Sweden”, Journal of Population Economics, 13(1), pp. 45-55.

Heckman J.-J. and G. Borjas (1980), "Does Unemployment Cause Future Unemployment ? Definitions, Questions and Answers from a Continuous Time Model of Heterogeneity and State Dependence", Economica, 47, pp. 247-283.

Henrekson, M. and M. Persson (2004), "The Effects on Sick Leave of Changes in the Sickness Insurance System”, Journal of Labor Economics 22(1), pp. 87-113.

Hesselius, P. (2007), “Does Sickness Absence Increase the Risk of Unemployment?", The Journal of Socio-Economics, 36 (2), pp. 288-310.

Idler, E. L. and Y. Benyamini (1997), "Self-rated Health and Mortality: Review of Twenty-seven Community Studies", Journal of Health and Social Behavior, 38, pp. 21-37.

Johnson, J. V., E. M. Hall and T. Theorell (1989), "Combined Effects of Job Strain and Social Isolation on Cardiovascular Disease Morbidity and Mortality in a Random Sample of the Swedish Male Working Population", Scandinavian Journal of Work, Environment \& Health, pp. 271-279.

Jürges, H. (2007), "True Health vs Response Styles: Exploring Cross-country Differences in Self-reported Health", Health Economics 16(2), pp. 163-178.

Jones, M. (2011), "Disability, Employment and Earnings: An Examination of Heterogeneity," Applied Economics, 43(8), pp. 1001-1017.

Johnsson, A., T. Fornander, L. Rutqvist, M. Olsson (2011), "Work Status and Life Changes in the First Year after Breast Cancer Diagnosis", Work, 38, pp. 337-346.

Joutard, X., A. Paraponaris, L. Sagaon-Teyssier, B. Ventelou (2012). "A Continuous-time Markov Model for Transitions Between Employment and Non-employment: the Impact of a Cancer Diagnosis", Annals of Economics and Statistics, 107-108, pp. 239-266.

Kalwij, A. and F. Vermeulen (2008), "Health and Labour Force Participation of Older People in Europe: What Do Objective Health Indicators Add to the Analysis?", Health Economics, 17(5), pp. 619-638.

Karasek Jr, R. A. (1979), “Job Demands, Job Decision Latitude, and Mental Strain: Implications for Job Redesign", Administrative science quarterly, pp. 285-308.

Karasek, R. A. and T. Theorell (1990). Healthy Work, Stress, Productivity, and the Reconstruction of Working Life. Basic Book. New-York.

Kim, J. and P. Moen, (2002), "Retirement Transitions, Gender, and Psychological Well-being: A LifeCourse Approach." Journal of Gerontology: Psychological Sciences 57B, pp. 212-222.

Kivimaki, M., M. Virtanen, M. Elovainio, A. Kouvonen, A. Vaananen and J. Vahtera (2006), 'Work Stress in the Etiology of Coronary Heart Disease - a Meta-analysis', Scandinavian Journal of Work, Environment \& Health, Vol. 32, No. 6, pp. 431-442.

Kuhn, A., R. Lalive and J. Zweimüller (2009), "The Public Health Costs of Job Loss", Journal of Health Economics, 28(6), pp. 1099-1115. 
Laaksonen, M., O. Rahkonen, P. Martikainen, E. Lahelma (2006), “Associations of Psychosocial Working Conditions with Self-rated General Health and Mental Health among Municipal Employees", International Archives of Occupational and Environmental Health, 79(3), pp. 205-212.

Leach, L., H. Christensen, A. Mackinnon, T. Windsor, P. Butterworth (2008), "Gender Differences in Depression and Anxiety across the Adult Lifespan: the Role of Psychosocial Mediators", Social Psychiatry and Psychiatric Epidemiology, 43(12), pp. 983-998.

Lindblom, K. (2006), "Burnout in the Working Population: Relations to Psychosocial Work Factors", International Journal of Behavioral Medicine, Vol. 13, No. 1, pp. 51-59.

Lindeboom, M. and M. Kerkhofs (2009), "Health and Work of the Elderly: Subjective Health Measures, Reporting Errors and Endogeneity in the Relationship between Health and Work", Journal of Applied Econometrics, 24(6), pp. 1024-1046.

Lindeboom, M. (2006), "Health and Work of Older Workers", in: A.M. Jones (ed.), Elgar Companion to Health Economics. Edward Elgar, Cheltenham.

Lindeboom, M., F. Portrait, G. van den Berg (2002), “An Econometric Analysis of the Mental-Health Effects of Major Events in the Life of Older Individuals", Health Economics, 11(6), pp. 505-20.

Lindbohm, M. -L., E. Kuosma, T. Taskila, P. Hietanen, K. Carlsen, S. Gudbergsson, Gunnarsdottir, (2011), "Cancer as the Cause of Changes in Work Situation", Psycho-oncology, 20, pp. 805-812.

Livanos, I and A. Zangelidis (2013), "Unemployment, Labour Market Flexibility and Absenteeism: A PanEuropean Study". Industrial Relations 52(2), pp. 492-515.

Llena-Noza, A. (2009), "The Effect of Work Status and Working Conditions on Mental Health in Four OECD Countries", National Institute Economic Review, 209(1), pp. 72-87.

Llena-Nozal, A., M. Lindeboom, F. Portrait (2004): "The Effect of Work on Mental Health: Does Occupation Matter?", Health Economics, pp. 1045-1062.

Loprest, P., R. Kalman et S. H. Sandell (1995), "Gender, Disabilities, and Employment in the Health and Retirement Study”, Journal of Human Resources, 30(5), pp. S293-S318.

Marie, O., J. Vall-Castello (2012), "Measuring the (Income) Effect of Disability Insurance Generosity on Labour Market Participation," Journal of Public Economics, 96(1), pp. 198-210.

Markussenn S. (2012), “The Individual Cost of Sick Leave”, Journal of Population Economics, 25(4), pp. 1287-1306.

Marmot, M. (2000). "Social Determinants of Health: from Observation to Policy". Medical Journal of Austria, 172: pp. 379-82

Marmot, M. and R. Wilkinson (1999), Social Determinants of Health, Oxford; Oxford University Press.

Mazzonna, F. and F. Peracchi (2012), “Ageing, Cognitive Abilities and Retirement”, European Economic Review, 56(4), pp. 691-710.

Mehnert, A. (2011), "Employment and Work-related Issues in Cancer Survivors", Critical Reviews in Oncology Hematology; 77, pp. 109-130. 
Mesrine A., (2000), "La surmortalité des chômeurs : un effet catalyseur du chômage ?", Economie et statistique, $\mathrm{n}^{\circ} 334$, pp 33-48.

Mujahid, M. S., N. K. Janz, S. T. Hawley, J. J. Griggs, A. S. Hamilton, J. Graff, S. J. Katz, (2011), "Racial/Ethnic Differences in Job Loss for Women with Breast Cancer", Journal of Cancer Survivorship, Research and Practice, 5, pp. 102-111.

Nelson, R. and J. Kim (2008): "Survival of the Fittest: Impact of Mental Illness on Employment Duration", Pharmacotherapy outcomes, Research Center, University of Utah.

Oberst K., C. J. Bradley, J. C. Gardiner, M. Schenk, C. W. Given (2010), "Work Task Disability in Employed Breast and Prostate Cancer Patients", Journal of Cancer Survivorship, Research and Practice, 4 (4), pp. 322-330.

OECD (2013), « Protéger l'emploi, renforcer la flexibilité : un nouveau regard sur la législation sur la protection de l'emploi », Les perspectives de l'emploi de l'OCDE (juillet 2013).

Origo, F. and L. Pagani (2009), "Flexicurity and Job Satisfaction in Europe: The Importance of Perceived and Actual Job Stability for Well-being at Work", Labour Economics, 16, pp. 547-555.

Ose, S.O. (2005), "Working Conditions, Compensation and Absenteeism". Journal of Health Economics, 24 , pp. 161-188.

Osthus, S. (2012), "Health Effects of Downsizing Survival and Job Loss in Norway", Social Science \& Medicine, 75(5), pp. 646-653.

Paraponaris, A., L. S. Teyssier, B. Ventelou (2010). "Job Tenure and Self-reported Workplace Discrimination For Cancer Survivors 2 Years After Diagnosis: Does Employment Legislation Matter?" Health Policy, 98 (2-3), pp. 144-155.

Partha, D., W. Gallo, P. Ayyagari, J. Fletcher, J. Sindelar (2011), "The Effect of Job Loss on Overweight and Drinking", Journal of Health Economics, 30(2), pp. 317-327.

Perronnin, M., A. Pierre, T. Rochereau (2011), "Complementary Health Insurance in France: Wide-Scale Diffusion but Inequalities of Access Persist", Issues in Health Economics (Questions d'économie de la santé), $\mathrm{n}^{\circ} 161$.

Plaisier, I., J. G. Bruijn, J. H. Smit, R. De Graaf, M. Ten Have, A. T. Beekman, R. Van Dyck, B.W. Penninx (2008), "Work and Family Roles and the Association with Depressive and Anxiety Disorders: Differences between Men and Women", Journal of Affective Disorders 105(1-3):63-72

Pollak, C., (2012). "Employed and Happy Despite Weak Health? Labour Market Participation and Job Quality of Older Workers with Disabilities", IRDES Institut for Research and Information in Health Economics, Working Papers DT45.

Quinlan E., R. Thomas-MacLean, T. Hack, W. Kwan, B. Miedema, S. Tatemichi, A. Towers, A. Tilley (2009) "The Impact of Breast Cancer among Canadian Women: Disability and Productivity", Work, 34 (3), pp. 285-296.

Reday-Mulvey, G. (2005), Working beyond 60: Key Policies and Practices in Europe, Palgrave Macmillan, New York. 
Robone S., A. Jones and N. Rice (2011), "Contractual Conditions, Working Conditions and Their Impact on Health and Well-being", European Journal of Health Economics, 12(5), pp. 429-444.

Rohwedder, S., R. Willis (2010), “Mental Retirement”, Journal of Economic Perspectives 24, pp. 1-20.

Santin, G., C. Cohidon, M. Goldberg, E. Imbernon (2009), "Depressive Symptoms and Atypical Jobs in France from the 2003 Decennial Health Survey", American Journal of Industrial Medicine, 52 (10), pp. 799-810.

Salm, M., (2009), "Does Job Loss Cause Ill Health?", Health Economics, 18(9), pp. 1075-1089.

Sobocki, P., B. Jonsson, J. Angst and C. Rehnberg (2006), "Cost of Depression in Europe”. Journal of Mental Health Policy and Economics, 9, pp. 87-98.

Shapiro, C, and J. E. Stiglitz (1984), "Equilibrium Unemployment as a Worker Discipline Device", The American Economic Review, 74(3), pp. 433-444.

Schmitz, H. (2011), "Why Are the Unemployed in Worse Health? The Causal Effect of Unemployment on Health", Labour Economics, 18(1), pp. 71-79.

Shmueli, A. (2003), "Socio-economic and Demographic Variation in Health and in its Measures: the Issue of Reporting Heterogeneity", Social Science and Medicine, 57 (1), pp. 125-134.

Siegrist, J. (1996), “Adverse Health Effects of High-effort/Low-reward Conditions"; Journal of Occupational Health Psychological, 1(1), pp. 27-41.

Sousa-Poza, A. and A. Sousa-Poza (2000), 'Well-being at Work: a Cross National Analysis of the Levels and Determinants of Job Satisfaction', Journal of Socio-Economics, Vol. 29, No. 6, pp. 517-538.

Staubli, S. (2011) “The Impact of Stricter Criteria for Disability Insurance on Labor Force Participation", Journal of Public Economics, 95(9-10), pp. 1223-1235.

Stronks, K., H. van de Mheen, C. Looman and J. Mackenbach (1997), "Cultural, Material, and Psychosocial Correlates of the Socioeconomic Gradient in Smoking Behavior among Adults". Preventive Medicine, 26(5), pp. 754-766.

Sverke, M., J. Hellgren and K. Naswall (2006). “Job Insecurity: A Literature Review”. Stockholm, Sweden: National Institute for Working Life.

Taskila-Abrandt, T, E. Pukkala, R. Martikainen, A. Karjalainen, P. Hietanen (2005), "Employment Status of Finnish Cancer Patients in 1997”, Psycho-oncology, 14 (3), pp. 221-226.

Tessier, P. et F. C. Wolff (2005), «Offre de travail et santé en France », Économie et Prévision, 168, pp.17-41.

Timming, A. R. (2010), 'Cross-national Variation in the Determinants of Job Satisfaction. How Far Do our Results “Travel”?', International Journal of Organization Theory and Behavior, Vol. 13, No. 4, pp. 525-545.

Vall-Castello, J. (2012), "Promoting Employment of Disabled Women in Spain; Evaluating a Policy", Labour Economics, 19(1), pp. 82-91. 


\section{ECO/WKP(2014)44}

Van der Hulst, M. (2003), "Long Work Hours and Health", Scandinavian Journal of Work, Environment and Health, 29(3), 171-188.

Van Rossum, C., H. van de Mheen, M. Breteler, D. Grobbee and J. Mackenbach (1999), "Socioeconomic Differences in Stroke among Dutch Elderly Women: the Rotterdam Study”, Stroke, 30(2), pp. 357362.

Wadsworth, M. E.J. (1999), "Early Life Hypothesis”, in M Marmot \& R. Wilkinson, eds., Social Determinants of Health, Oxford University Press, Oxford.

Waenerlund, A. K., P. Virtanen and A. Hammarstrom (2011): "Is Temporary Employment Related to Health Status? Analysis of the Northern Swedish Cohort", Scandinavian Journal of Public Health, 39 , pp. 533-539.

Weich, S. and G. Lewis (1998), "Material Standard of Living, Social Class, and the Prevalence of the Common Mental Disorders in Great Britain", Journal of Epidemiology and Community Health, 52(1), pp. 8-14.

Zhang, X., X. Zhao, A. Harris (2009), "Chronic Diseases and Labour Force Participation in Australia", Journal of Health Economics, 28, pp. 91-108. 
ECO/WKP(2014)44

\section{WORKING PAPERS}

The full series of Economics Department Working Papers can be consulted at www.oecd.org/eco/workingpapers

1147 Making the best of new energy resources in the United States

(July 2014) by Douglas Sutherland

1146. Improving well-being in the United States

(July 2014) by Aida Caldera Sánchez, Patrick Lenain and Sarah Fléche

1145. Deconstructing Canada's housing markets: finance, affordability and urban sprawl

(July 2014) by Calista Cheung

Restructurer les marchés canadiens du logement : financements, accessibilité financière et étalement urbain

(Juillet 2014) par Calista Cheung

1144. Women's role in the Swiss economy

(July 2014) by Richard Dutu

Le rôle des femmes dans l'économie suisse

(Juillet 2014) par Richard Dutu

1143. Overcoming skills shortages in Canada

(July 2014) by David Carey

Combler les pénuries de compétences au Canada

(Juillet 2014) par David Carey

1142. Trade patterns in the 2060 world economy

(July 2014) by Jean Chateau, Lionel Fontagné, Jean Fouré, Åsa Johansson and Eduardo Olaberria

1141. The Demand for Skills 1995-2008: A global chain perspective

(July 2014) by Bart Los, Marcel P. Timmer and Gaaitzen J. De Vries

1140. International migration: The relationship with economic and policy factors in the home and destination country

(July 2014) by Ben Westmore

1139. Gross earning inequalities in OECD countries and major non-member economies: determinants and future scenarios

(July 2014) by Henrik Braconier and Jenifer Valenzuela Ruiz

1136. Long-term patterns of trade and specialisation

(July 2014) by Asa Johansson and Eduardo Olaberria

1135. Consequences of climate change damages for economic growth - a dynamic quantitative assessment

(July 2014) by Rob Dellink, Elisa Lanzi, Jean Chateau, Francesco Bosello, Ramiro Parrado and Kelly de Bruin

1134. Comparing the robustness of $P A Y G$ pension schemes

(July 2014) by Falilou Fall 
1133. Overcoming vulnerabilities of pension systems

(July 2014) by Falilou Fall and Debbie Bloch

1132. Overcoming vulnerabilities of health care systems

(July 2014) by Mauro Pisu

1131. Overcoming vulnerability of unemployment insurance schemes (July 2014) by Jon Pareliussen

1130. Vulnerability of social institutions: Lessons from the recent crisis and historical episodes (July 2014) by Falilou Fall, Mauro Pisu, Jon Pareliussen and Debbie Bloch

1129. An update of the OECD international trade equations

(June 2014) by Myriam Morin and Cyrille Schwellnus

1128. What explains the volume and composition of trade? Industrial evidence from a panel of countries

(June 2014) by Asa Johansson, Przemyslaw Kowalski, Eduardo Olaberria and Dario Pellegrino

1127. Do resources flow to patenting firms: cross-country evidence from firm level data (June 2014) by Dan Andrews, Chiara Criscuolo and Carlo Menon

1126. Macroprudential policy tools in Norway: Strengthening financial system resilience (June 2014) by Yosuke Jin, Patrick Lenain and Paul O’Brien

1125. Strengthening competition in Poland

(June 2014) by Balász Égert and Antoine Goujard

1124. Making the labour market work better in Poland

(June 2014) by Hervé Boulhol

1123. Enhancing competition and the business environment in Hungary

(June 2014) by Alvaro Pina

1122. Tackling labour mismatches and promoting mobility in Hungary

(June 2014) by Stéphane Sorbe

1121. Local public finances and municipal reform in Finland

(June 2014) by Christophe André and Clara Garcia

1120. The economic consequences of ageing: the case of Finland

(June 2014) by Christine de la Maisonneuve, Christophe André, Clara Garcia and Vincent Koen

1119. Making the most of skills in Denmark

(June 2014) by Stéphanie Jamet and Vincent Koen

1118. Trade specialisation and policies to foster competition and innovation in Denmark (June 2014) by Müge Adalet McGowan 